\title{
Study on Morpho-Physiological Characters in Different Clones of Sugarcane (Saccharum officinarum L.)
}

\author{
Sadras Bhavana*, M. Vijay Kumar, G.S. Madhu Bindu and D.V.V. Reddy
}

Agricultural Research Station, Basanthpur-Mamidigi, Medak Dist., Telangana, India

*Corresponding author

\begin{tabular}{|c|}
\hline \\
\hline $\begin{array}{l}\text { Sugarcane, } \\
\text { Morphological, } \\
\text { Physiological, SCMR- } \\
\text { SPAD chlorophyll } \\
\text { meter reading, } \\
\text { Chlorophyll } \\
\text { fluorescence, LAI- } \\
\text { leaf area index. }\end{array}$ \\
\hline Article Info \\
\hline $\begin{array}{l}\text { Accepted: } \\
\text { 04 September } 2017 \\
\text { Available Online: } \\
10 \text { November } 2017\end{array}$ \\
\hline
\end{tabular}

\section{Introduction}

Sugarcane, an industrial crop was grown in an area of 50.321 ha with a cane production of 356.56 Mt and a productivity of $70.86 \mathrm{t} \mathrm{ha}^{-1}$ in India during 2014-15. It occupied an area of 49,000 ha with a cane production of $3.67 \mathrm{Mt}$ and a productivity of $75 \mathrm{t} \mathrm{ha}^{-1}$ in the state of Telangana in 2014-15. India ranks second in terms of area and per hectare productivity. Sugarcane being a $\mathrm{C}_{4}$ plant is distinct and more efficient converter of solar energy, thus having potential to produce huge amounts of biomass. Plant development and growth are basic processes that define crop yield. Development and growth of crop can be estimated based on their morphophysiological parameter study. The relative effects of yield components as stalk number, stalk length, stalk thickness, stalk density on cane yield studied through path coefficient analysis by Khairwal and Babu (1975) revealed that the stalk number was the most important one deciding the yield. Besides inherent varietal efficacy, the stalk population is influenced by seed rate, spacing and 
cultural practices (Roach, 1976). Similarly, Herbert et al., (1965) observed a strong and positive association between cane yield and stalk population. Tiller is a primordial characteristic of sugarcane; it is the main sink product of photosynthesis. The tiller dynamics in sugarcane is a genotype effect; it is tailored by several factors (Van Dillewijn, 1952; Ramesh and Mahadevaswamy, 2000). Sugarcane, plant height alone was a good predictor of plant biomass at all stages of growth. Though, it is basically a genetically controlled character, it is being influenced by environmental conditions and management practices (Vijay Kumar, 2012). Bell and Garside (2005) at Queensland, Australia noted wide variation when stalk population density and individual stalk dry mass was related with yield.

Sugarcane leaves are the main path for water loss via transpiration, absorption of photosynthetically active radiation (PAR), and carbon assimilation via photosynthesis. These processes together allow for the provision of energy and organic molecules necessary for growth and development of the whole plant. Leaf area determines the amount of incident PAR intercepted by the crop canopy and ultimately dry matter production and the transformation of solar energy into chemical energy during photosynthesis is directly related to yield (Sandhu et al., 2012). Partitioning of dry matter in sugarcane is of interest for two fundamental reasons. Firstly, sugar production depends directly on partitioning of crop biomass to the stalk and then to sucrose stored largely in stalk parenchyma. Secondly, various dry matter components of the stalk and particularly sucrose concentration are used to calculate the value of cane consignments delivered to the mill (Inman-Bamber, 2002).

Analysis of chlorophyll content (SPAD) is important for evaluating the health or integrity of the internal apparatus during photosynthetic process within a leaf (Ronghua et al., 2006; Clark et al., 2000) and provides a rapid and accurate technique of detecting and quantifying plants tolerant to drought stress (Rong-hua et al., 2006). Chlorophyll fluorescence ratio $(\mathrm{Fv} / \mathrm{Fm})$ values used to estimate the extent of drought-induced photo-inhibition. RWC represents a useful indicator of the state of water balance of a plant, essentially because it expresses the absolute amount of water, which the plant requires to reach artificial full saturation.

\section{Materials and Methods}

The present study was conducted at Agricultural Research Station, BasanthpurMamidigi, Medak Dist. which comes under Central Telangana Zone, Telangana during 2016-2017. The information regarding experimental details, and statistical techniques were collected. The weather data on rainfall, number of rainy days, mean maximum and minimum temperatures and relative humidity recorded from June'16 to April'17 at the meteorological observatory of Agricultural Research Station, Basanthpur are presented in Appendix 1 and depicted in figure 1 .

The highest mean maximum and minimum temperature recorded was $41.9^{\circ} \mathrm{C}$ and $11.6^{\circ} \mathrm{C}$ in the month of February ' 17 and November '16 respectively. Highest mean monthly relative humidity recorded was $58.6 \& 88.5 \%$ in forenoon and afternoon in the month of October and September respectively. The total of $1072.6 \mathrm{~mm}$ of rainfall was received during the crop in 51 rainy days (Table 1).

The root study was conducted on a specially constructed raised rectangular root structures each of size $1 \mathrm{~m} \mathrm{x} 1 \mathrm{~m} \times 1.2 \mathrm{~m}$ ( $\mathrm{L} \times \mathrm{B} \times \mathrm{Ht})$. A total of three blocks of katcha root structures, each block containing 12 structures were constructed specially with bricks and cement. Each structure was filled with soil up to $1.2 \mathrm{~m}$ level (layout and Fig. 2). 
The field experiment was conducted with 12 varieties in randomized block design replicated thrice. The 12 varieties/clones studied were Co 94008, Co 99006, Co 99004, Co 86032, Co C 92061, 85 R 186, 83 R 23, Co 95020, Co 8014, Co C 671, 97 R 129 and 97 R 401. Planting, fertilization, irrigation and harvesting were done as per the recommended practices in order to quantify the growth and yield of the crop raised in root structures. Accordingly, single node seedlings @ 12 no.s were planted in each root structure.

Morphological parameters like number of tillers, plant height, and number of leaves per plant, number of nodes, internodal length and dry matter per structure were considered. The shoot population i.e., number of tillers were counted at 90 and 120 DAP and were expressed in thousands per hectare ('000 ha' ${ }^{1}$ ). Plant height was measured from the base of the plant to the top fully opened leaf of the main shoot at harvest. Measurements were taken from the main shoots at 60,120, 150, 240 DAP and at harvest and average height of the single plant was calculated and expressed in $\mathrm{cm}$.

Number of fully opened leaves on the main shoot was counted at 60,120 and 150 DAP. Measurements were taken from the main shoots at the above stages and average leaf number per plant was expressed. Number of nodes on the main shoot was counted at harvest. Measurements were taken from the main shoots and average node number per plant was expressed. Length of middle internodes was measured at harvest by using scale and expressed in $\mathrm{cm}$. Plants from the structure were cut at the base and separated in to leaf, stem and were dried at $80^{\circ} \mathrm{C}$ to a constant weight at harvest. The data dry matter was expressed in $\mathrm{g}$ per structure.

Physiological parameters like SCMR, Fv/Fm, RWC and LAI were observed for twelve genotypes. The SPAD (Soil Plant Analytical Development) meter is a simple hand held and portable instrument which provides information on the relative amount of leaf chlorophyll. The SCMR was measured on index leaf i.e., third leaf from the top at formative stage using SPAD meter of Minolta Company, NJ, USA (SPAD 502). The unit less measurement obtained from SPAD chlorophyll meter is based on the differences light attenuation at $430 \mathrm{~nm}$ (peak wavelength for chlorophyll a and b) and that at $750 \mathrm{~nm}$ (near infrared) with no transmittance. Thus SPAD chlorophyll meter reading represents chlorophyll concentrations in the leaf (Rao et al., 2001). While reading SCMR, care was taken to ensure that the SPAD meter sensor fully covered the leaf lamina.

Chlorophyll fluorescence was measured at formative stage (120 DAP). Chlorophyll fluorescence characteristics were measured on intact leaves using a pulse amplitude modulation fluorometer (Model 0S5-FL, Opti-Sciences, Tyngsboro, MA, USA), and used to estimate the extent of drought-induced photo-inhibition. During measurement, at least four leaves per root structure were darkadapted for $30 \mathrm{~min}$ using leaf clips (FL-DC, Opti-Science) before fluorescence measurements.

The relative water content was estimated by the method prescribed by Barrs and Weatherly (1962). Ten discs from the leaves of three clumps were collected randomly in each variety and weighed accurately up to fourth decimal on an electrically operated single pan analytical balance. This was considered as the fresh weight. The weighed leaf discs were allowed to float on distilled water in a petri dish and allowed to absorb water for four hours. After four hours the leaf discs were taken out and their surface was blotted gently and weighed. This was referred to as turgid weight after drying these leaf 
discs in an oven at $70^{\circ} \mathrm{C}$ for 48 hours, the dry weight was recorded and designated as dry weight. The RWC was calculated by the following formula.

$$
\begin{aligned}
& \text { Fresh weight - Dry weight } \\
& \begin{array}{c}
\text { RWC (\%) = ---------------------- x } 100 \\
\text { Turgid weight — Dry weight }
\end{array}
\end{aligned}
$$

Leaf area index (LAI) is the ratio between the leaf area and ground area. The leaves were calculated at monthly intervals with help of a factor computed by taking the area of 50 leaves taken at random in each root structure. The length and breadth of same leaves were taken and the factor was calculated (Bathla and Sharma, 1978).

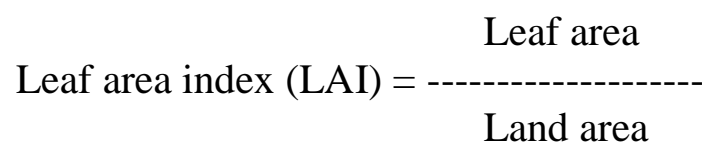

\section{Results and Discussion}

\section{Tiller population}

The data recorded on shoot population at 90 and 120 DAP has shown significant differences among the varieties. Shoot population increased in all the varieties up to 120 days after planting. Initially at 90 DAP, the tiller population was highest with the variety Co 86032 (89520 ha $\left.{ }^{-1}\right)$.Further, the varieties Co 95020 and Co C 671 were found at par to Co 86032 with tiller population of 80160 and 84680 ha $^{-1}$. However, similar trend was not seen at 120 DAP where the variety Co 86032 alone stood best with significantly highest tiller population as compared to the other varieties. The variety, Co 86032 genotypically characterized by profuse tillering and medium thick stalked canes has maintained higher tiller population than the other varieties. On contrary, the lowest tiller population was noticed for the varieties, $97 \mathrm{R}$ 401, Co 99006, Co C 92061, 85 R 186, Co
99004 and Co 8014 at both 90 and 120 DAP. Javed et al., (2011) and also found similar significant differences among the varieties for tiller population.

\section{Plant height}

In sugarcane, plant height alone was a good predictor of plant biomass at all stages of growth. The plant height of different varieties increased with the advancement of crop growth and varied significantly among the varieties. Among the varieties, Co 95020 stood best with significantly highest plant height at all the stages of crop growth and the height increased from $102.39 \mathrm{~cm}$ at 90 DAP to $338.33 \mathrm{~cm}$ at harvest. However, it was found at par to the varieties, Co 86032, Co C 671 and Co 94008 which recorded plant heights equivalent to Co 95020. The above varieties being genotypically tall to medium tall in nature might have put forth greater plant heights compared to the other varieties. Further, it was recorded lowest for variety 97 $\mathrm{R} 401$ at all the stages. As the crop growth advanced from 120 DAP to harvest, the increment in plant height in varieties, $83 \mathrm{R}$ 23, Co 8014, Co 99006 and Co C 92061 was less as compared to the best varieties and they performed at par to $97 \mathrm{R} 401$ with respect to plant height. Similar findings were made by Charumathi and Naidu (2015).

\section{Number of leaves per plant}

Sugarcane leaves are the main path for water loss via transpiration, absorption of photosynthetically active radiation (PAR), and carbon assimilation via photosynthesis. Number of green leaves were more at 150 or 180 DAP i.e., during peak formative stage. The differences in number of leaves per plant were significant among the varieties at all stages of crop growth. Further, Mean number of green leaves increased from 3.48 at 60 days to 13.27 at 180 days of planting. 
At 60 DAP, the varieties Co 94008, Co 99006, Co 99004, Co 86032, Co C 92061, Co 95020, 97 R 129 and 97 R 401 being at par were found superior to the remaining varieties with maximum number of leaves ranging from 3.46 to 3.91 per plant.

Whereas, 85 R 186, 83 R 23 and Co 8014 had significantly lowest number of leaves ranging from 2.77 to 3.11 per plant. The mean leaf numbers increased from 3.48 to 6.55 per plant at 120 DAP.

The variety, Co 86032 having narrow erect leaves had put forth significantly highest leaf number (8.41) over the other varieties indicating its rapid growing nature.

With the advancement of crop growth up to 180 DAP, the varieties Co 99004, 85 R 186, 83 R 23, Co 95020 and Co 8014 had picked up the growth and performed equivalent to the best variety Co 86032 with respect to the leaf number. The varieties, Co C 92061 and $97 \mathrm{R}$ 401 however had recorded lowest leaf number compared to the other varieties.

\section{Number of nodes}

Number of nodes per plant also has shown significant variations among the varieties. It were maximum in varieties, Co C 92061, 83 R 23, 97 R 129 and 97 R 401 ranging from 23.49 to 25.39. Further, the lowest node number was observed with the varieties $\mathrm{Co}$ 86032, 85 R 186 and Co C 671. The result may be in response of genotypic character of the individual varieties.

\section{Internodal length}

Similar to the number of nodes, the internodal length of different Sugarcane varieties was found significant. The internodal length was at par and maximum with the varieties $\mathrm{Co}$ $86032(16.27 \mathrm{~cm})$ and Co C $671(15.68 \mathrm{~cm})$. The internodal length in the remaining varieties ranged from 9.64 to $14.05 \mathrm{~cm}$ (Table 2; Fig. 3).

Table.1 Monthly mean meteorological data during the crop growth period

\begin{tabular}{|c|c|c|c|c|c|c|c|}
\hline \multirow{2}{*}{ S No. } & \multirow{2}{*}{ Months } & \multicolumn{2}{|c|}{ Temperature $\left({ }^{\circ} \mathbf{C}\right)$} & \multicolumn{2}{|c|}{$\begin{array}{c}\text { Relative } \\
\text { Humidity }(\%)\end{array}$} & \multirow{2}{*}{$\begin{array}{c}\text { Rainfall } \\
(\mathbf{m m})\end{array}$} & \multirow{2}{*}{$\begin{array}{c}\text { Rainy } \\
\text { Days } \\
\text { No.s }\end{array}$} \\
\hline & & Min & $\operatorname{Max}$ & FN & $\mathbf{A N}$ & & \\
\hline 1 & June (2016) & 21.1 & 37.6 & 15.6 & 75.4 & 215.2 & 12 \\
\hline 2 & July & 21.2 & 33.6 & 31.0 & 74.3 & 233.2 & 12 \\
\hline 3 & August & 21.3 & 30.2 & 17.9 & 83.0 & 89.8 & 9 \\
\hline 4 & September & 21.4 & 27.0 & 40.1 & 88.5 & 461.8 & 15 \\
\hline 5 & October & 20.9 & 25.4 & 58.6 & 52.5 & 64 & 1 \\
\hline 6 & November & 11.6 & 29.4 & 20.0 & 86.6 & 0.0 & 0 \\
\hline 7 & December & 11.9 & 27.3 & 25.7 & 86.5 & 1.2 & 0 \\
\hline 8 & January (2017) & 12.2 & 27.7 & 18.6 & 24.2 & 0.0 & 0 \\
\hline 9 & February & 13.8 & 41.9 & 13.0 & 65.3 & 0.0 & 0 \\
\hline 10 & March & 18.0 & 32.9 & 10.8 & 60.8 & 7.4 & 2 \\
\hline 11 & April & 16.6 & 30.5 & 12.3 & 58.6 & 6.2 & 2 \\
\hline
\end{tabular}


Table.2 Mean performance of sugarcane varieties raised in root structures for morphological (growth) characters

\begin{tabular}{|c|c|c|c|c|c|c|c|c|c|c|c|c|c|c|}
\hline \multirow[t]{2}{*}{ S.No. } & \multirow[t]{2}{*}{ Variety } & \multicolumn{2}{|c|}{ Tiller Count } & \multicolumn{5}{|c|}{ Plant Height } & \multicolumn{3}{|c|}{ No. of Leaves } & \multirow{2}{*}{$\begin{array}{c}\begin{array}{c}\text { No of } \\
\text { nodes }\end{array} \\
\text { per } \\
\text { plant } \\
\text { At } \\
\text { harvest }\end{array}$} & \multirow{2}{*}{$\begin{array}{c}\begin{array}{c}\text { Inter } \\
\text { nodal } \\
\text { Length } \\
(\mathrm{cm})\end{array} \\
\text { At } \\
\text { harvest }\end{array}$} & \multirow{2}{*}{$\begin{array}{l}\text { Total dry } \\
\text { matter } \\
\text { (g) } \\
\text { At } \\
\text { harvest }\end{array}$} \\
\hline & & $\begin{array}{c}90 \\
\text { Days }\end{array}$ & $\begin{array}{c}120 \\
\text { Days }\end{array}$ & $\begin{array}{c}90 \\
\text { Days }\end{array}$ & $\begin{array}{c}120 \\
\text { Days }\end{array}$ & $\begin{array}{c}150 \\
\text { Days }\end{array}$ & $\begin{array}{c}240 \\
\text { Days }\end{array}$ & $\begin{array}{c}\text { At } \\
\text { Harvest }\end{array}$ & $\begin{array}{c}60 \\
\text { Days }\end{array}$ & $\begin{array}{c}120 \\
\text { Days }\end{array}$ & $\begin{array}{c}180 \\
\text { Days }\end{array}$ & & & \\
\hline 1 & Co 94008 & 79.12 & 125.63 & 88.22 & 118.74 & 135.73 & 178.97 & 302.18 & 3.54 & 6.38 & 11.43 & 21.75 & 11.07 & 3917.6 \\
\hline 2 & Co 99006 & 64.4 & 111.5 & 78.27 & 105.47 & 120.96 & 157.86 & 275.47 & 3.49 & 6.12 & 12.42 & 20.83 & 12.60 & 3004.4 \\
\hline 3 & Co 99004 & 69.22 & 119.54 & 80.25 & 110.1 & 128.62 & 172.98 & 294.33 & 3.78 & 6.29 & 14.63 & 21.55 & 13.30 & 4082.4 \\
\hline 4 & Co 86032 & 89.52 & 148.36 & 96.11 & 128.17 & 144.37 & 184.9 & 322.12 & 3.91 & 8.41 & 15.91 & 18.50 & 16.27 & 4141.867 \\
\hline 5 & Co C 92061 & 65.24 & 112.17 & 78.75 & 107.43 & 123.42 & 160.86 & 281.57 & 3.77 & 6.25 & 11.00 & 25.39 & 9.64 & 3024.4 \\
\hline 6 & 85 R 186 & 67.14 & 116.30 & 86.96 & 115.12 & 133.63 & 173.56 & 299.79 & 2.77 & 6.11 & 14.41 & 19.00 & 11.14 & 3604.4 \\
\hline 7 & 83 R 23 & 72.37 & 122.88 & 75.57 & 100.4 & 113.51 & 152.71 & 263.03 & 3.24 & 6.18 & 14.27 & 23.49 & 11.27 & 3678 \\
\hline 8 & Co 95020 & 80.16 & 130.27 & 102.3 & 132.92 & 148.33 & 199.57 & 338.33 & 3.88 & 7.07 & 14.51 & 21.51 & 14.05 & 3974 \\
\hline 9 & Co 8014 & 70.17 & 120.64 & 75.25 & 103.71 & 117.93 & 155.15 & 263.21 & 3.11 & 6.32 & 14.51 & 21.09 & 12.36 & 3860 \\
\hline 10 & Co C 671 & 84.68 & 130.47 & 90.88 & 121.25 & 138.74 & 181.01 & 307.35 & 3.32 & 6.51 & 13.52 & 17.63 & 15.68 & 3434 \\
\hline 11 & 97 R 129 & 75.24 & 124.99 & 83.09 & 112.02 & 128.53 & 179.48 & 295.86 & 3.46 & 6.51 & 13.08 & 24.29 & 11.44 & 2909.6 \\
\hline 12 & 97 R 401 & 61.02 & 105.15 & 55.01 & 89.31 & 105.81 & 149.63 & 256.11 & 3.49 & 6.4 & 9.62 & 23.72 & 9.68 & 2719.067 \\
\hline Mean & & 73.19 & 122.32 & 82.56 & 112.05 & 128.3 & 170.56 & 289.83 & 3.48 & 6.55 & 13.27 & 21.56 & 12.38 & 3529.14 \\
\hline $\begin{array}{c}\text { CD } \\
(P=0.05)\end{array}$ & & 10.19 & 17.51 & 14.78 & 18.72 & 19.45 & 22.73 & 38.36 & 0.53 & 0.85 & 1.7 & 2.93 & 1.51 & 569.1 \\
\hline
\end{tabular}


Table.3 Mean performance of sugarcane varieties raised in root structures for physiological characters

\begin{tabular}{|c|c|c|c|c|c|}
\hline S.No. & Variety & SCMR & FV/Fm Ratio & RWC (\%) & LAI \\
\hline 1 & Co 94008 & 39.86 & 0.42 & 72.3 & 6.01 \\
\hline 2 & Co 99006 & 41.55 & 0.44 & 75.7 & 5.42 \\
\hline 3 & Co 99004 & 40.82 & 0.44 & 79.7 & 5.58 \\
\hline 4 & Co 86032 & 39.63 & 0.4 & 78.1 & 6.59 \\
\hline 5 & Co C 92061 & 39.89 & 0.42 & 73.9 & 5.47 \\
\hline 6 & 85 R 186 & 48.25 & 0.52 & 82.2 & 5.74 \\
\hline 7 & 83 R 23 & 40.74 & 0.42 & 71.3 & 6.03 \\
\hline 8 & Co 95020 & 51.19 & 0.52 & 83.9 & 6.42 \\
\hline 9 & Co 8014 & 39.85 & 0.35 & 70.8 & 5.87 \\
\hline 10 & Co C 671 & 40.41 & 0.42 & 69.2 & 5.58 \\
\hline 11 & 97 R 129 & 42.82 & 0.46 & 75.4 & 5.27 \\
\hline 12 & 97 R 401 & 41.28 & 0.38 & 73.2 & 5.22 \\
\hline \multicolumn{2}{|c|}{ Mean } & 42.19 & 0.43 & 75.5 & 5.77 \\
\hline \multicolumn{2}{|c|}{$\mathrm{CD}(\mathrm{P}=\mathbf{0 . 0 5})$} & 5 & 0.07 & 9.58 & 0.64 \\
\hline
\end{tabular}

Fig.1 Meteorological data showing Temperature, Relative Humidity and Rainfall during the crop period (2016-2017)
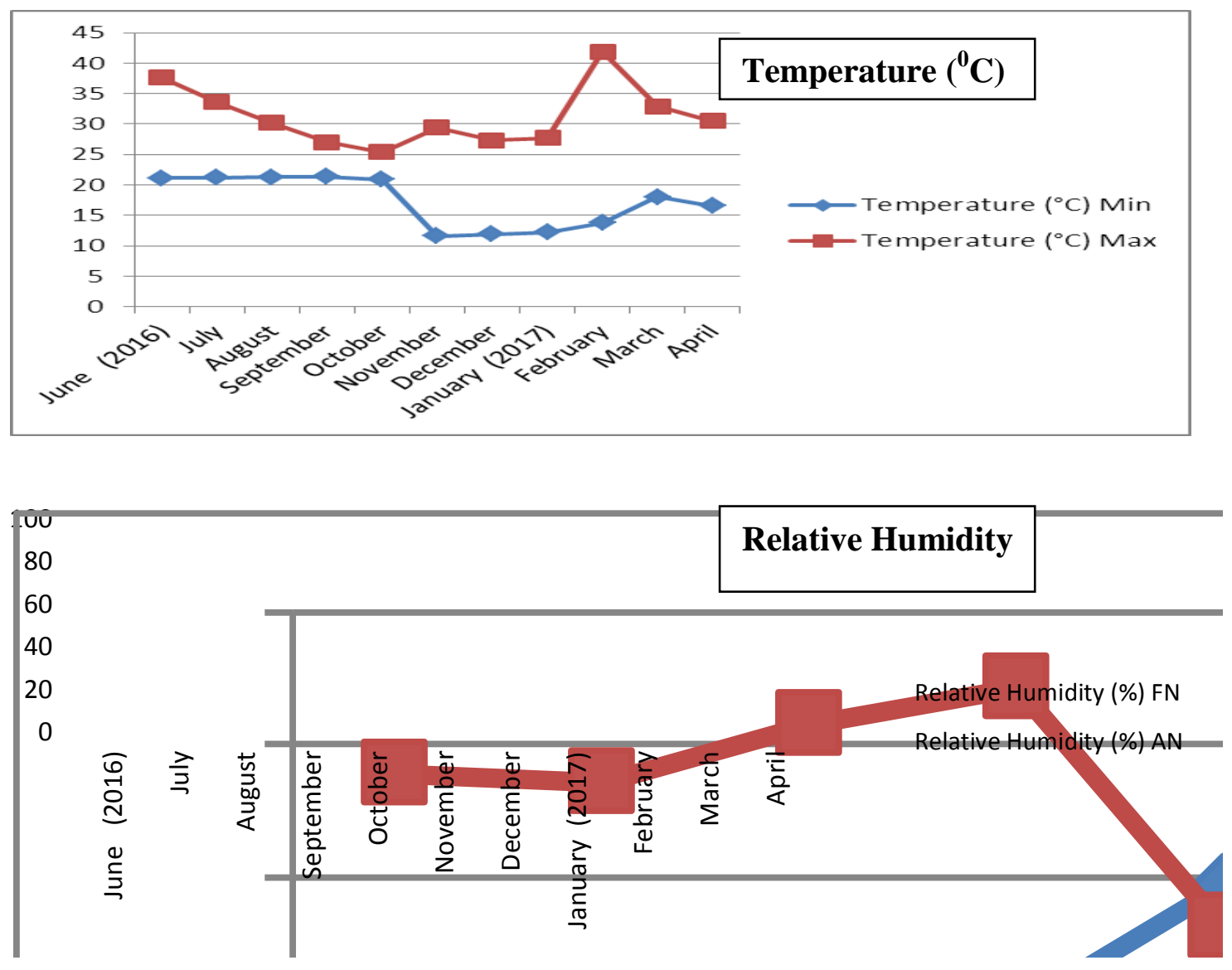


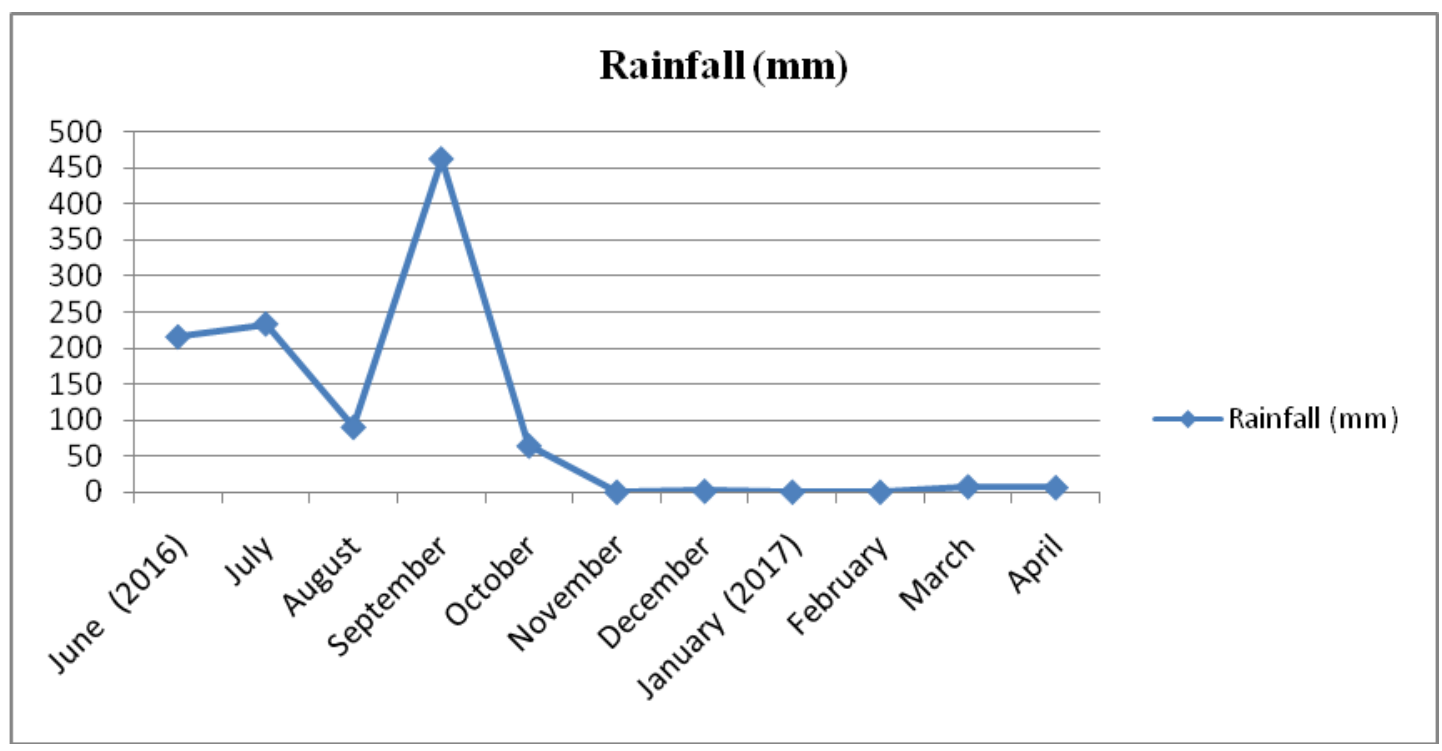

Fig.2 Root structure

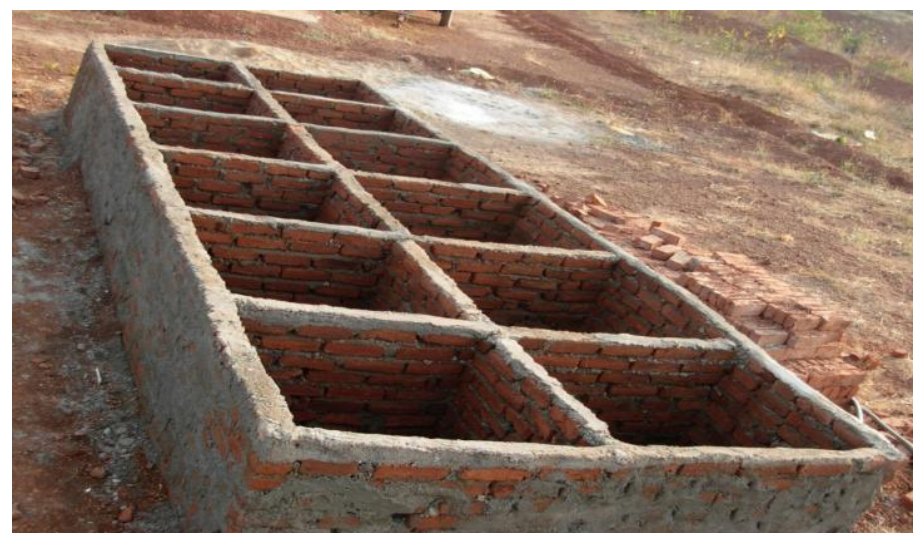

Fig.3 Mean performance of sugarcane varieties raised in root structures for morphological characters

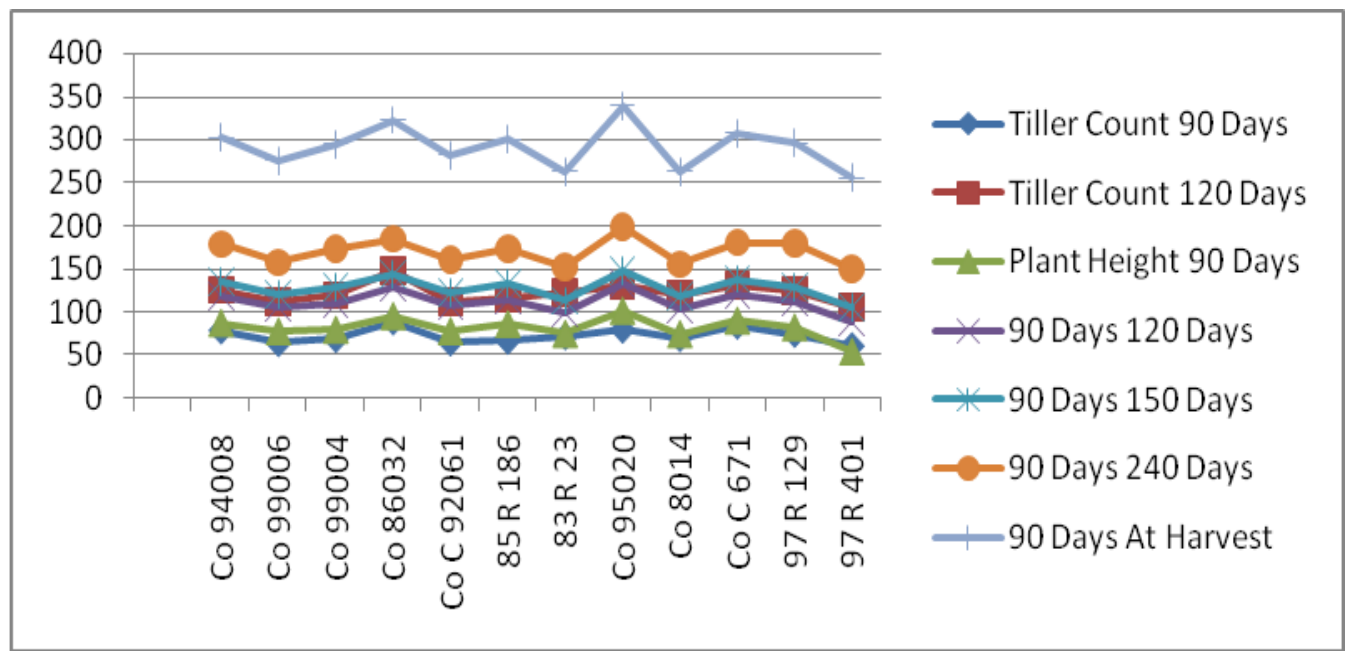



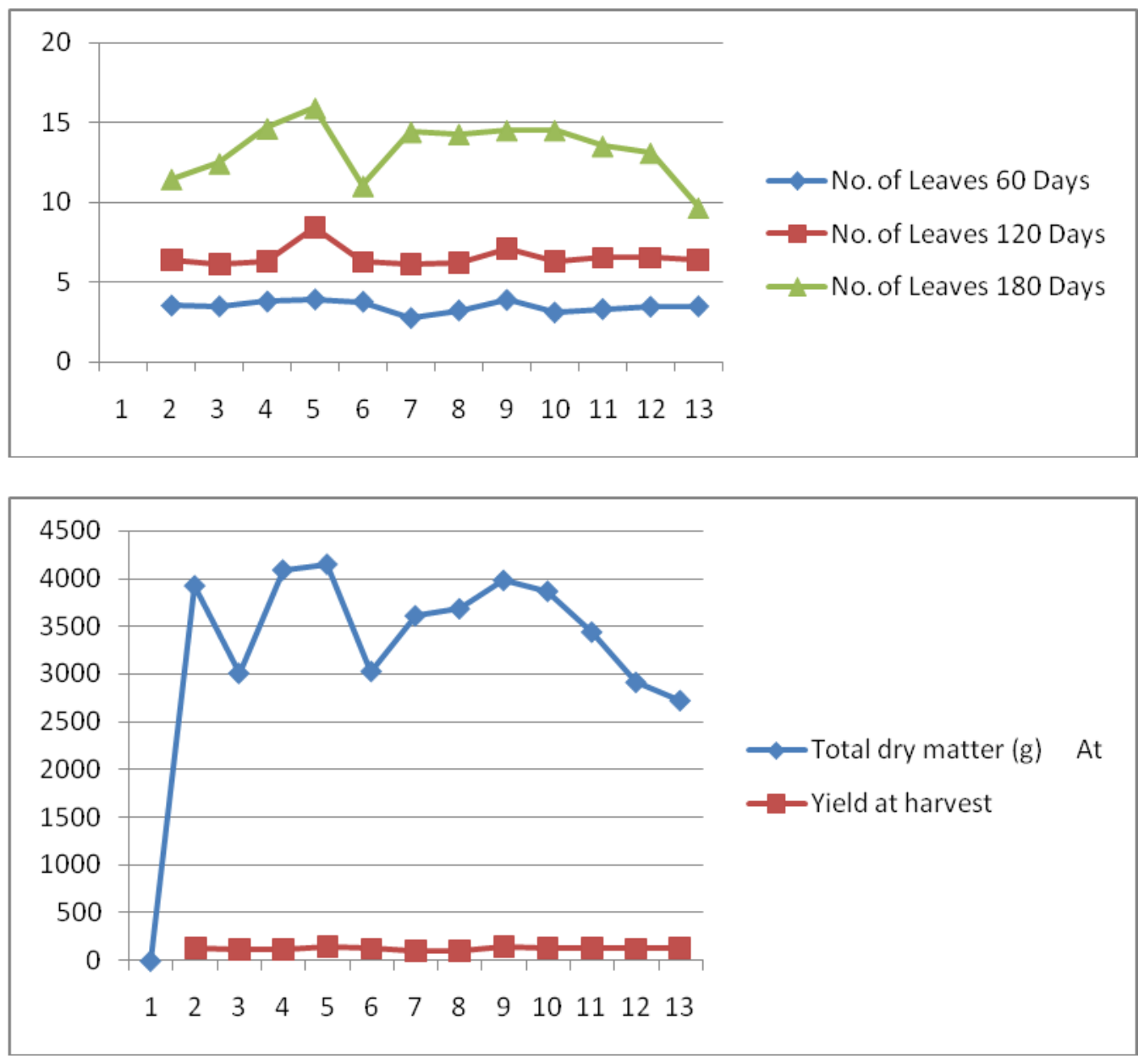

Fig.4 Mean performance of sugarcane varieties raised in root structures for Physiological characters

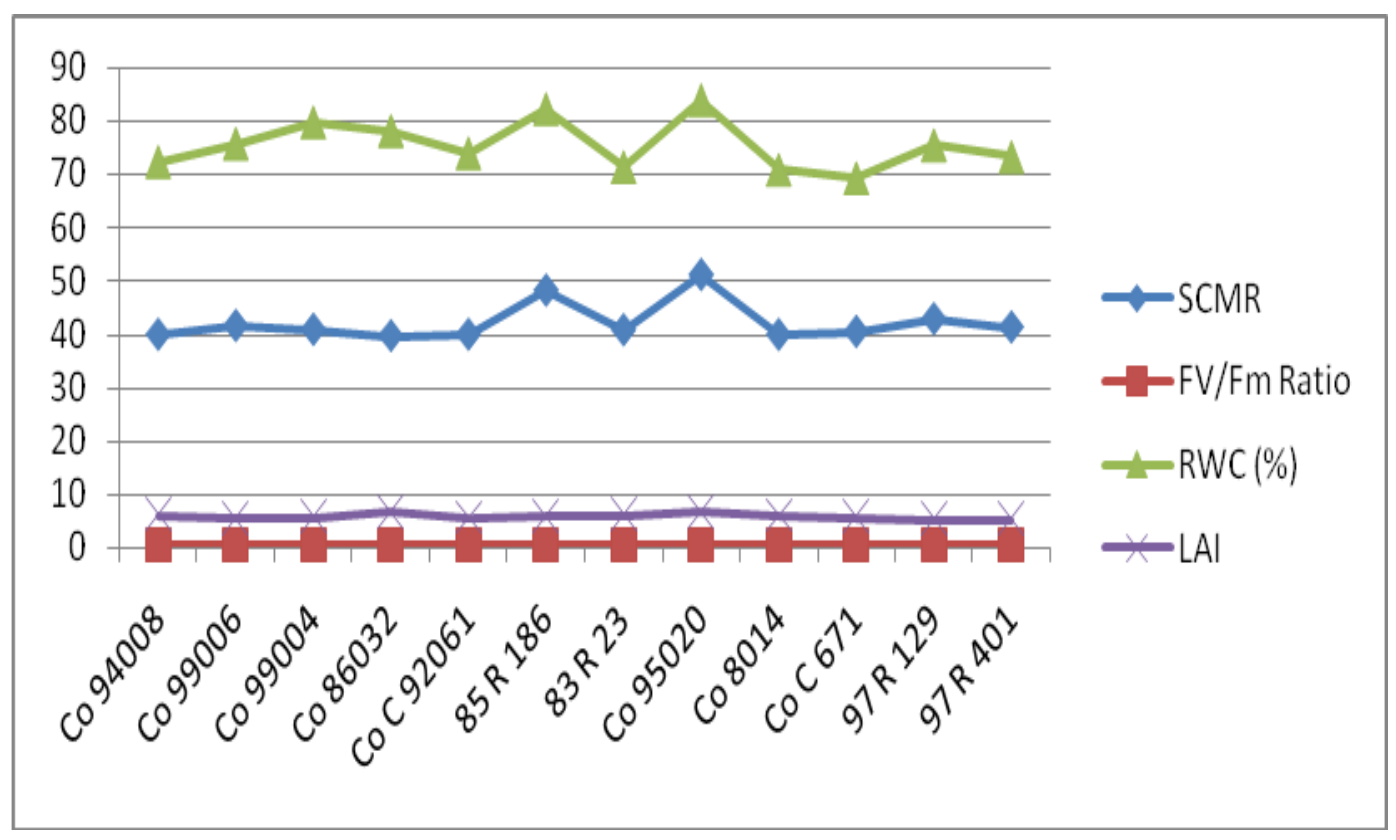




\section{Layout of the Root Structure}

R1

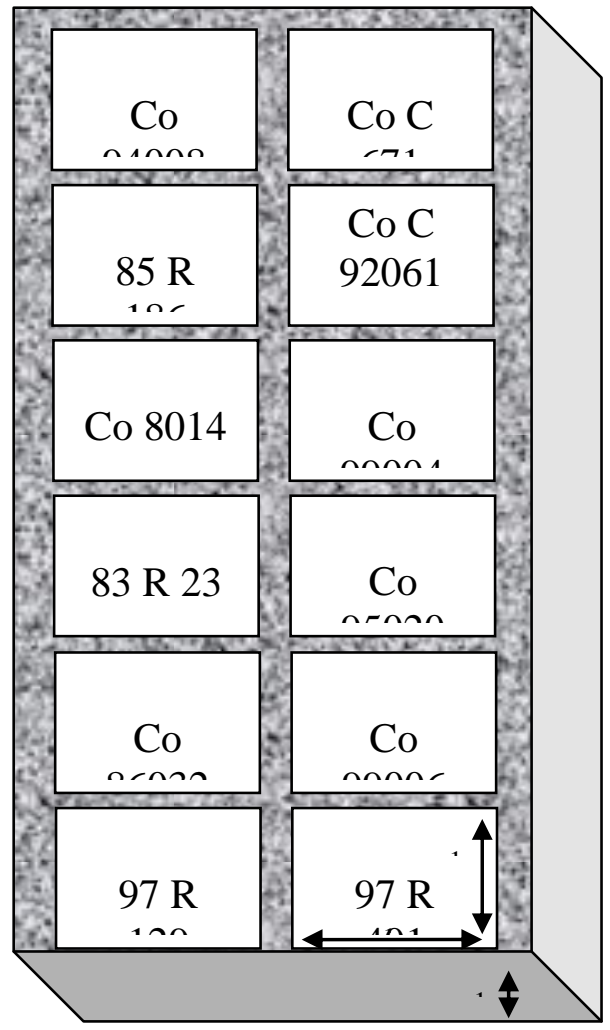

Dry matter production

The total dry matter produced per structure was determined at harvest. It showed significant differences among the varieties and ranged from 22.94 to $34.79 \mathrm{t} \mathrm{ha}^{-1}$. Significantly highest dry matter production was recorded with the varieties, Co 86032 (4142 g), Co 99004 (4082 g), Co 95020 (3974 g), Co 94008 (3918 g), Co 8014 (3860 g), 83 R 23 (3678 g) and 85 R 186 (3604 g).

These varieties being at par were found superior to the remaining varieties. Better performance of the above varieties in terms of tiller number, plant height and number of leaves has reflected in dry matter production. Similar findings were noted by Lonsdale and
$\mathrm{R} 2$

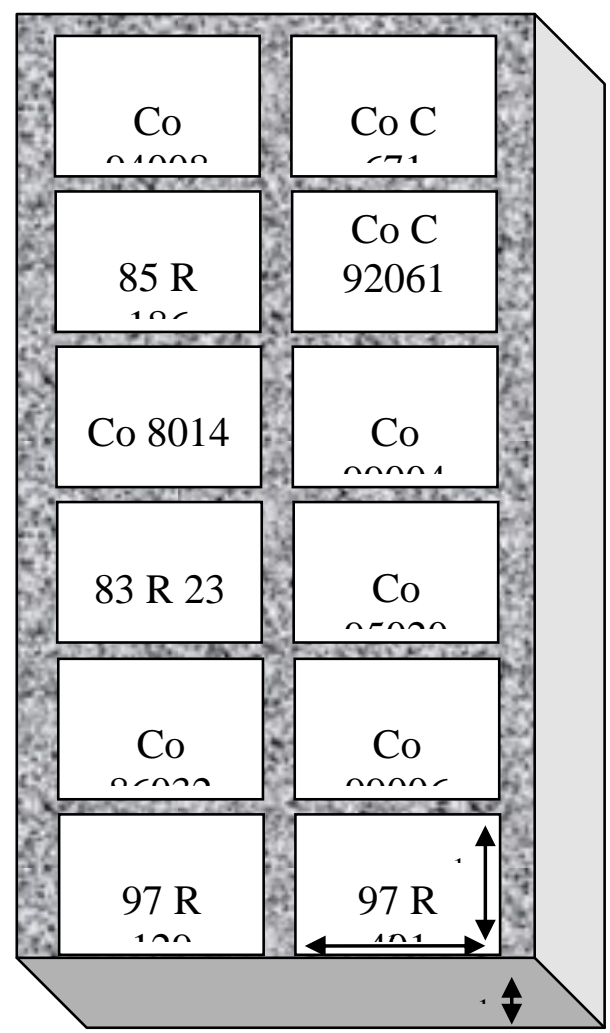

R3

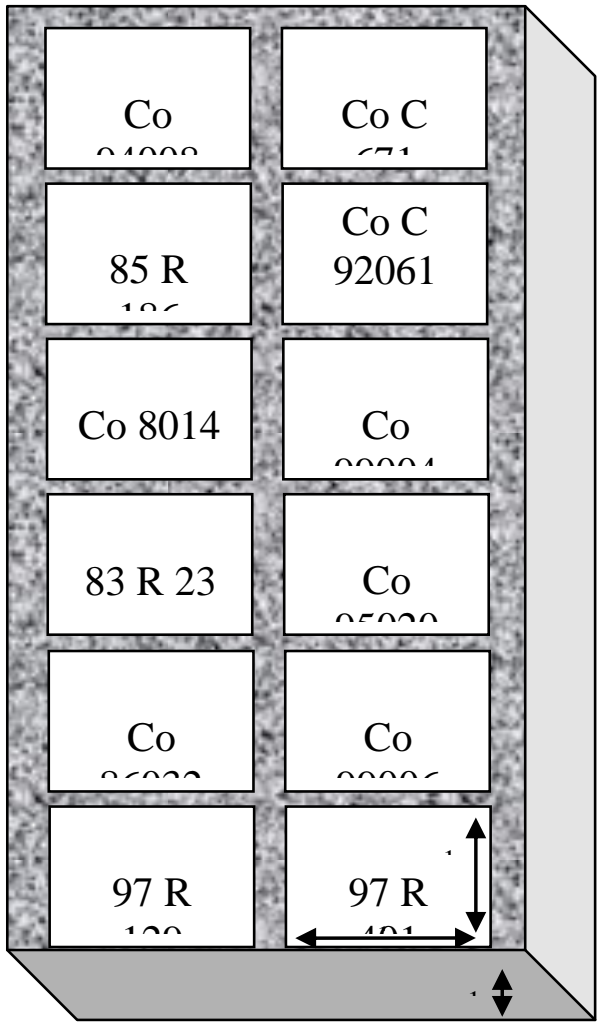

Gosnell (1976). Lower tiller population, shorter plants, less number of leaves in the varieties, $97 \mathrm{R}$ 401, $97 \mathrm{R}$ 129, Co 99006 and Co C 92061 has ultimately resulted in the production of lowest dry matter and it ranged from 2719 to $3024 \mathrm{~g}$ at harvest.

\section{Physiological characters}

\section{SPAD chlorophyll meter readings}

Photosynthetically active radiation is absorbed by chlorophyll and accessory pigments of chlorophyll-protein complexes and it migrates to the reaction centres of PS I and II, where the conversion of the quantum photosynthetic process takes place (Rong-hua et al., 2006). 
The mean SPAD values varied significantly with different varieties. The mean values of the SPAD were significantly highest with the varieties 85 R 186 and Co 95020. These varieties being at par had recorded SPAD values ranging from 48.25 to 51.19. All the other varieties had recorded lowest mean SPAD values ranging from 39.63 to 42.82 . The results obtained were similar to those reported by Mukunda Rao et al., (2011). The distribution of SCMR among the sugarcane genotypes used in this study is consistent with their tolerance-susceptibility classification. Further, the varieties, 85 R 186 and Co 95020 showing high values of SPAD chlorophyll meter readings (SCMR) especially during the mild stress condition at formative stage in root structures. This indicates the above varieties were relatively tolerant to drought conditions (Table 3; Fig. 4).

\section{Chlorophyll fluorescence (Fv/Fm)}

Significant differences due to varieties were observed for photosystem II (PSII) photochemical efficiency $\left(\begin{array}{lll}F & { }_{\mathrm{v}} / F & \mathrm{~m}\end{array}\right)$ measurements. Owing to higher chlorophyll content, the chlorophyll fluorescence values were also highest with the varieties $85 \mathrm{R} 186$ and Co 95020. The variety, $97 \mathrm{R} 129$ was also found at par to the above varieties. The more the capacity to maintain a high $\mathrm{Fv} / \mathrm{Fm}$ ratio by the above varieties could indicate a high efficiency of radiation use, possibly by carbon assimilation reactions (Silva et al., 2007). On the other hand, Co 94008, Co 86032, Co C 92061, 83 R 23, Co 8014, Co C 671 and 97 R 401 being at par recorded significantly lowest chlorophyll fluorescence values.

\section{Relative water content}

RWC represents a useful indicator of the state of water balance of a plant, essentially because it expresses the absolute amount of water, which the plant requires to reach artificial full saturation. The relative water content of sugarcane was significantly influenced by the varieties. The relative water content in different genotypes ranged from 69.2 to 83.9 per cent. The genotype Co 95020 maintained higher tissue water content $(83.9 \%)$ at formative stage. However, the varieties, 85 R 186 (82.2\%), Co 99004 (79.7\%) and Co 86032 (78.1\%) were found at par to Co 95020 with respect to relative water content. On the other hand, lower tissue water contents were noted in the varieties, Co C 671 (69.2\%), Co 8014 (70.8\%), 83 R 23 (71.3\%), Co 94008 (72.3\%) and 97 R 401 (73.2\%). The varieties, Co 99006 (75.7\%), 97 R 129 (75.4\%) and Co C 92061 (73.9\%) were found to be statistically equivalent to both highest and lowest varieties for relative water content. The higher SCMR values of Co 95020 and 85 $\mathrm{R} 186$ had shown positive reflectance on relative water content. The results are in accordance to Silva et al., (2013).

\section{Leaf Area Index}

The data on leaf area index in different varieties had shown significant variations. Leaf area index observed at harvest ranged from 5.22 to 6.59. This was in accordance with earlier findings which reported that LAI in Sugarcane ranged from 3 to 6 between 150 and 330 days age and the differences were observed with variety (Anonymous 1980-81 and Ramos and Rosario, 1977). The varieties, Co 86032, Co 95020, 83 R 23 and Co 94008 recorded significantly highest leaf area index and were found comparable to each other. Higher LAI of these varieties may be due to higher shoots per unit area. It was observed that higher LAI also resulted in more dry matter production in these varieties. Conversely, lowest leaf area index was observed with the varieties $97 \mathrm{R} 401,97 \mathrm{R}$ 129, Co 99006, Co C 92061, and Co 99004, Co C 671 and 85 R 186. The lower LAI of these varieties was found to be due to lower 
stalk population and higher mortality of shoots.

\section{Cane yield}

Cane yield is the ultimate manifestation of morphological, physiological, biochemical processes and growth parameters. Habib et al., (1991) had reported that yield attributes viz., stalk height and girth improves cane yield per unit area to greater extent.

The data on cane yield recorded after harvest indicated significant difference among the varieties. The cane yield of different varieties ranged from 96.15 to $142.66 \mathrm{t} \mathrm{ha}^{-1}$. The varieties, Co 86032 (142.66 t ha $\left.{ }^{-1}\right)$, Co 95020 (140.32 $\left.\mathrm{t} \mathrm{ha}^{-1}\right)$, Co C 671 (130.52 $\left.\mathrm{t} \mathrm{ha}^{-1}\right)$ and $97 \mathrm{R} 401$ (126.20 $\left.\mathrm{t} \mathrm{ha}^{-1}\right)$ being at par had recorded significantly highest cane yields over the remaining varieties. Better yield attributes viz., number of millable canes; cane height, cane girth and single cane weight along with better morpho-physiological parameters viz., plant height, no. of leaves, long internodes, high dry matter production, high SPAD reading and relative water content of the above varieties might had resulted in higher cane yields. On the other hand, lowest cane yields were observed with the varieties, $85 \mathrm{R} 186$ (96.15 $\left.\mathrm{t} \mathrm{ha}^{-1}\right), 83 \mathrm{R} 23$ (101.26 t $\left.\mathrm{ha}^{-1}\right)$ and Co 99004 (109.20 t ha $\left.{ }^{-1}\right)$.

\section{Acknowledgement}

It is by the immense blessing of Thy Lord for grace and blessings showered on me in each and every step of my life, that I could utilize this opportunity. I am pleased to place my profound etiquette to Dr. M. Vijay kumar, Senior Scientist \& Head (Crop Physiology), ARS, Basanthpur, Medak Dist. Further I wish to express my deep sentiments of gratitude and reverence to Dr. G. S Madhu bindu, Department of Agronomy, ARS, Basanthpur, Medak dist. For their counsel, unstinted attention and meticulous guaidance on thw work at all stages and have installed in me the spirit of confidence to successfully complete the task. I further extend my sincere thanks to Mr. Shiv Sai for helping me in analysis and research work in collection and compilation of data. Last but not least I want to thank all my friends who helped and encouraged me in conducting my research work from starting to end.

\section{References}

Anonymous.1980-81. Annual report of Regional Agricultural Research Station, Rudrur.

Barrs, H.D. and Weatherley, P.E. 1962. A reexamination of the relative turgidity technique for estimating water deficits in leaves. Aust. J. Biol. Sci. 15: 413 428.

Bathla, H.V.L. and Sharma, H.L. 1978. Measurement of leaf area in sugarcane. Indian Sugar Crops J. 5 (1):16.

Bell, M.J., and Garside, A.L. 2005. Shoot and Stalk dynamics and the yield of sugarcane crops in tropical and subtropical overseas-land Australia. Field Crop Res. 92 (2-3):231-248.

Charumathi, M. and Naidu, N.V. 2015.Promising high yielding and sucrose rich early maturing clones suitable for east coast zone of India. Int. J. of Agric. Innovations and Res. 4(3): pp 547-552.

Clark, A.J., W. Landolt, J.B. Bucher and Strasser, R.J. 2000. Beech (Fagus sylvatica) response to ozone exposure assessed with a chlorophyll fluorescence performance index. Environ Pollute. 109: 501-507.

Habib, G., Malik, K.B and Chatha, M.Q. 1991. Preliminary evaluation of exotic sugarcane varieties for quantitative characters. I. Pakistan J. Agric. Res. 12:95-101. 
Herbert Leo, Matherne, R.J. and Davidson, L.G. 1965. Row spacing experiments with Hsiao, T. C. 1973. Plant responses to water stress. Ann. Rev. Plant Physiol. 27: 519-570.

Javed, I., Mahmood ulHassan., Bashir, S., Khan, M.Z., Yasin, M., and Ahmad, S. 2011. Response of promising sugarcane clones/varieties under Agro ecological conditions of Faisalabad. Sugarcane Res. Inst., Faisalabad. pp: 1-7.

Khairwal, I.S. and Babu, C.N. 1975. Path coefficient analysis of cane yield in sugarcane. ISST, Sugarcane Breeder's newsletter.36: 58.

Lonsdale, J.E. and Gosnell, J.M. 1976. Growth and quality of four sugarcane varieties influenced age and season. Proc. of The S Afr. Sugar Technologists' Assoc. pp:82-86.

Mukunda Rao, Ch., Raja Rajeswari, V. and Naidu, N.V. 2011. Identification of sugarcane clones suitable for early planting under moisture stress/drought situations of North coastal region of Andhra Pradesh. Ind. sugar. pp: 31-34.

Ramos, A.I. and Rosario, E.L. 1977. Growth characteristics of three sugarcane varieties differing in net carbon exchange. Philip. J. Crop Sci. I: 113116.

Rao, R.C.N., Talwar, H.S. and Wright, G.C. 2001. Rapid assessment of SLA and leaf nitrogen in peanut (Arachis hypogaea L.) using chlorophyll meter. Crop Sci.186: 175-182.

Roach, B.T. 1976. Observation on the effect of row space on sugarcane yield.Proc. 45th. Conf. Old So Res.

Rong-hua, L., Pei-guo, G., Baum, M., Grando, S. and Ceccarelli, S. 2006. Evaluation of chlorophyll content and fluorescence parameters as indicators of drought tolerance in barley. Agric. Sci. China. 5: 751-757.

Sandhu, H.S., Gilbert, R.A., McCray, J.M., Pedomo, R., Eiland, B., Powell, G. and Montes, G. 2012. Relationships among Leaf Area Index, Visual growth rating and Sugarcane yield. J. Am. Soc. of Sugarcane Technol. 32: 1-14.

Silva, M.A., Jifon, J.L., da Silva, J.A.G. and Sharma, V. 2007.Use of physiological parameters as fast tools to screen for drought tolerance in sugarcane. Braz. $J$. plant Physiol. 19(3): 193-201.

Silva, M.A., Jifon, J.L., Santos, C.M.D., Jadoski, C.J and da Silva, J.A.G. 2013. Photosynthetic capacity and water use efficiency in sugarcane genotypes subject to water deficit during early growth phase. Braz. Arch. of Biol. and Tech. 56(5): 735-748.

Van Dillewijn, C. 1952. Botany of sugarcane. The Chronica Botanica Co Waltham N.A. pp: 371.

Vijay Kumar, M. 2012. Studies on physiological and biochemical characters related to drought resistance in sugarcane (Saccharum officinarum.L). Ph.D Thesis submitted to Acharya N. G. Ranga Agricultural University, Hyderabad.

\section{How to cite this article:}

Sadras Bhavana, M. Vijay Kumar, G.S. Madhu Bindu and Reddy, D.V.V. 2017. Study on Morpho-Physiological Characters in Different Clones of Sugarcane (Saccharum officinarum L.). Int.J.Curr.Microbiol.App.Sci. 6(11): 205-217. doi: https://doi.org/10.20546/ijcmas.2017.611.025 